\title{
EFEKTIVITAS METODE DEBAT AKTIF DAN STRATEGI PENERAPANNYA DALAM MENGOPTIMALKAN PEMBELAJARAN GEOGRAFI
}

\section{THE EFFECTIVENESS OF ACTIVE DEBATE METHOD AND ITS' STRATEGY TO OPTIMIZING GEOGRAPHY LEARNING}

\author{
Pradika Adi Wijayanto \\ (Pendidikan Geografi Pascasarjana Universitas Negeri Malang) \\ e-mail: pradikaadiwijayanto@gmail.com \\ Sugeng Utaya \& Ach. Amirudin \\ (Universitas Negeri Malang) \\ e-mail: sugengutaya@yahoo.com, ach.amirudin@fis.um.ac.id
}

Naskah diterima tanggal: 17-04-2017, disetujui tanggal: 24-06-2017

\begin{abstract}
This study is to expose the effectiveness of the active debate method in supporting student activity in geography learning as well as to find the appropriate strategy to optimize it. This study was a case study by taking ninth-grade students of social science class of SMA Negeri 1 Mayong of academic year 2016/2017 and it was conducted within three meetings. Data were based on observation, documents, and students' activeness sheet, and analyzed with percentage description by using determined criteria to conclude the result. Meanwhile, detailed strategy concerned effective method was based on the participant observation followed by checking member performance and implementation. The results showed that student activity for the first meeting was good, for the second meeting was very good, and for the third meeting was very good as well. In conclusion, the effectiveness of active debate method in geography learning is very good. The strategy applied also contributed to optimize students' activity.
\end{abstract}

Keyword: learning effectiveness, active debate method, geography learning

\begin{abstract}
Abstrak: Tujuan penelitian ini adalah mengetahui efektivitas penerapan metode debat aktif dalam mendukung tingkat keaktifan siswa pada pembelajaran geografi sekaligus menguraikan strategi tepat untuk mengoptimalkannya. Penelitian ini merupakan studi kasus dengan menggunakan subjek penelitian kelas XI IS 1 SMA Negeri 1 Mayong tahun ajaran 2016/2017 dilakukan selama tiga kali pertemuan. Teknik pengumpulan data berasal dari observasi partisipan, dokumentasi, dan lembar keaktifan siswa. Teknik analisis data menggunakan deskripsi persentase kemudian dikonsultasikan dengan kriteria yang ditentukan untuk menyimpulkan hasil penelitian sedangkan uraian strategi dalam mengefektifkan berdasarkan data hasil observasi partisipan kemudian dilakukan member check dan diimplementasikan. Analisis data hasil penelitian menunjukkan bahwa persentase keaktifan siswa pada pertemuan pertama masuk dalam kategori baik, persentase keaktifan siswa pada pertemuan berkategori sangat baik, persentase keaktifan siswa pada pertemuan ketiga juga berkategori sangat baik. Dengan demikian, efektivitas penerapan metode debat aktif dalam pembelajaran geografi adalah sangat baik. Strategi yang diterapkan juga mempunyai andil dalam mendukung persentase keaktifan siswa sehingga lebih optimal dari sebelumnya.
\end{abstract}

Kata kunci: efektivitas pembelajaran, debat aktif, pembelajaran geografi 


\section{PENDAHULUAN}

Paradigma pendidikan abad 21 berdampak pada pergeseran dalam sistem pembelajaran, yaitu yang semula berpusat pada guru berubah menjadi berpusat pada siswa (Badan Standar Nasional Pendidikan, 2010; Trilling \& Fadel, 2009). Perubahan tersebut mendorong para akademisi pendidikan dunia untuk menghasilkan berbagai jenis strategi, metode dan model pembelajaran dalam mewujudkan tujuan pendidikan. Salah satu metode yang digunakan untuk menunjang pembelajaran aktif dan bermakna dalam pembelajaran adalah metode debat aktif.

Metode debat aktif adalah metode pembelajaran yang unik karena mendorong siswa untuk aktif bekerja sama dan berkompetisi dalam pembelajaran. Zulyetti (2014) mengung-kapkan bahwa metode debat aktif pertama kali diperkenalkan Melvin L. Silberman. Penerapan metode debat aktif tepat dilakukan untuk mendukung paradigma pendidikan abad 21, yang didukung oleh berbagai keunggulan yang ada dapat membantu guru dalam meningkatkan efektivitas pembelajaran. Keunggulan metode debat aktif menurut Djunadi (2010) adalah dapat mengembangkan dan membangkitkan daya kreativitas maupun daya tarik peserta didik. Kelebihan lain ditegaskan Ismail (2008) bahwa metode debat aktif bermanfaat untuk peserta didik agar membiasakan mencari argumentasi kuat yang berguna untuk memecahkan suatu masalah kontroversial. Selain itu penerapannya dapat berfungsi untuk mengembangkan sikap demokratis dan saling menghormati terhadap perbedaan pendapat. Kelebihan lain metode debat aktif juga didukung oleh pendapat Shoimin (2014) dan Marsidjo (1990) dalam mendukung pembelajaran.

Kelebihan metode debat aktif tersebut juga diperkuat oleh hasil penelitian sebelumnya yang membuktikan bahwa metode debat aktif layak digunakan untuk mengatasi masalah dan mendukung peningkatan kualitas pembelajaran di kelas. Hasil penelitian Djunadi (2010) menunjukkan metode active debate terbukti efektif digunakan pada pembelajaran sosiologi. Hasil penelitian Mashudi \& Kholis (2015) membuktikan metode debat aktif mendukung peningkatan hasil belajar pada pembelajaran teknik elektro. Nurdin (2016) membuktikan metode debat aktif mampu meningkatkan keterampilan diskusi pembelajaran Pendidikan Kewarganegaraan. Pramesswari, Widodo \& Qosyim (2016) menunjukkan metode debat aktif dapat mendukung peningkatan keterampilan berpikir kritis pembelajaran Ilmu Pengetahuan Alam; Sudarmawanto \& Buditjahjanto (2012) membuktikan metode debat dapat meningkatkan hasil dan motivasi belajar pada pembelajaran teknik elektro; dan Zulyetti (2014) menunjukkan metode debat aktif dapat meningkatkan keterampilan berbicara dan hasil belajar pada pembelajaran Bahasa Indonesia.

Fakta dari kelebihan dan keberhasilan dalam penelitian tersebut menjadi landasan kuat dalam penerapannya. Dalam penerapannya akan memunculkan permasalahan jika dilakukan tanpa pengalaman dan persiapan yang matang. Kelemahan metode debat aktif pernah diungkapkan oleh Shoimin (2014) dan Marsidjo (1990) dalam pembelajaran. Kelebihan dan kelemahan tersebut sangat disayangkan tidak didukung oleh Melvin L. Silberman karena di dalam bukunya yang berjudul Active Learning 101 Strategies to Teach Any Subject tidak menyebutkan sama sekali, sehingga menimbulkan miskonsepsi jika tidak dibuktikan.

Penelitian yang dilakukan di SMA Negeri 1 Mayong ini bertujuan untuk mengetahui dampak metode debat aktif sehingga siswa yang kurang aktif menjadi lebih baik lagi yang ditandai dari perubahan tingkah laku dalam aktivitas pembelajaran. Pertimbangan lain dalam penerapan metode tersebut disebabkan belum pernah diterapkan dalam pembelajaran geografi. Peran dari penerapan metode debat aktif dalam penelitian ini diharapkan dapat bermanfaat untuk membuktikan efektivitas metode debat aktif yang diperkuat dengan menemukan strategi 
yang tepat untuk mengoptimalkan penerapannya sehingga berguna sebagai referensi baru dalam bidang pendidikan.

\section{METODE}

Penelitian ini adalah studi kasus yang dilakukan di SMA Negeri 1 Mayong tahun ajaran 2016/ 2017. Penelitian dilakukan selama tiga kali pertemuan dengan subjek penelitian di kelas XI IS 1 sebanyak 37 siswa. Pengambilan data berasal dari observasi partisipan untuk menggambarkan aktivitas dalam pembelajaran secara apa adanya. Dokumentasi untuk mendukung hasil observasi dan lembar keaktifan dibuat Mufidah (2012) mengadopsi indikator yang disusun menurut Krathwohl \& Bloom dalam Winkle (1996) sehingga aspek yang dinilai berupa kehadiran, keseriusan dalam mengikuti kegiatan pembelajaran, partisipasi individu dalam kelompok, diskusi dan debat dalam kelas, keseriusan, dan ketepatan waktu mengumpulkan tugas. Data tersebut kemudian dideskripsikan secara kualitatif untuk mengetahui efektivitas penerapan metode debat aktif. Data lembar keaktifan tersebut digunakan untuk mengetahui keaktifan siswa pada tiap pertemuan, kemudian dianalisis dengan menggunakan rumus deskripsi persentase. Selanjutnya dikonsultasikan dengan kriteria berdasarkan (Ridwan, 2015) yaitu 81\%-100 \% (Sangat baik), $61 \%-80 \%$ (Baik), 41\%-60\%(Sedang), 21\%40\% (Buruk), 0\%-20\% (Buruk Sekali). Prosedur dalam mengajukan strategi dalam mengoptimalkan penerapan metode debat aktif dilatarbelakangi oleh permasalahan yang ditemukan pada hasil observasi partisipan. Langkah selanjutnya diadakan pengecekan keabsahan data dengan cara member check (memeriksa dan mendiskusikan dengan anggota peneliti) yaitu guru mata pelajaran geografi sekaligus mencari referensi yang mendukung untuk menyimpulkan hasil yang tepat kemudian diimplementasikan jika memungkinkan karena waktu penelitian yang terbatas.

\section{HASIL DAN PEMBAHASAN \\ Penerapan Metode Debat Aktif \\ Pembelajaran Geografi Pertemuan Pertama}

Obervasi dilakukan selama tiga kali pertemuan, yang bertujuan untuk mengidentifikasi kelemahan yang terjadi dalam penerapan metode debat aktif. Pertemuan pertama dilakukan dengan waktu 105 menit karena jatah waktu untuk pembelajaran geografi dilakukan seminggu dua kali. Pembelajaran dimulai dengan penjelasan materi oleh guru selama 30 menit pada Kompetensi Dasar (KD) mendeskripsikan pemanfaatan lingkungan hidup dalam kaitannya dengan pembangunan berkelanjutan dengan materi lingkungan hidup dan permasalahannya. Guru menggunakan metode ceramah dan metode tanya jawab untuk mendukung penyampaian materi tersebut. Namun masih banyak siswa yang hanya diam dalam pembelajaran, sehingga bisa disimpulkan bahwa dalam pembelajaran ini belum tampak keaktifan yang signifikan. Masalah tersebut melatarbelakangi pentingnya penerapan metode debat aktif dalam pembelajaran geografi agar memberikan dampak positif.

Penerapan metode debat aktif yang dilakukan menggunakan prosedur berdasarkan Silberman (2006). Guru pertama kali memilih tema dan menjelaskan masalah kontroversial yang terjadi di sekitar lingkungan siswa, yaitu terkait "aktivitas galian C Nalumsari Jepara meresahkan, Satpol PP hanya bisa memberi peringatan". Permasalahan ditemukan saat guru melaksanakannya. Permasalahan tersebut muncul ketika penjelasan dari guru kurang bisa dipahami oleh kebanyakan siswa. Sehingga siswa terlibat melakukan tanya jawab yang memakan waktu banyak dengan guru, padahal guru sudah menggunakan media iSpring Suite dalam kegiatan ini. Mengatasi permasalahan tersebut guru berinisiatif membagikan artikel yang dicetak dan menambah konten video dengan durasi 3 menit pada media iSpring Suite. Namun cara tersebut masih perlu peninjauan ulang karena isi artikel terlalu panjang dan 
konten video diambil terbatas pada wilayah lain. Hal tersebut kurang pas digunakan dan pembagian artikel setelah menjelaskan berakibat pada penambahan waktu. Selanjutnya guru membagi siswa yang ada di dalam kelas menjadi dua kelompok besar (pro dan kontra). Ganjalan ditemukan dalam pembagian subkelompok debat. Hal tersebut dilatarbelakangi bahwa siswa lebih senang berkumpul dengan teman akrabnya saja, sehingga sempat terjadi gangguan. Opsi awal yang dilakukan guru adalah membagi subkelompok berdasarkan jadwal piket, sehingga dianggap mencerminkan keadilan. Anggapan tersebut ternyata tidak terbukti karena secara langsung menimbulkan benturan dengan prosedur penerapan metode debat aktif. Jadwal piket siswa terdiri dari 6 kelompok sedangkan prosedur menyatakan bahwa subkelompok harus dibagi menjadi dua sampai empat saja. Mengetahui ketidakrelevanan opsi tersebut maka guru membagi siswa berdasarkan deretan meja sehingga dalam subkelompok antara siswa laki-laki dan perempuan terbagi rata menjadi 3 subkelompok pro dan kontra yang masing-masing terdiri dari 6-7 siswa.

Sebelum kegiatan debat di depan kelas dimulai, guru mempersilahkan tiap subkelompok mendiskusikan kembali terkait artikel yang telah dibagikan selama 10 menit. Artikel tersebut bertujuan untuk menganalisis permasalahan apa yang sebenarnya terjadi dan bagaimana sikap siswa menanggapi permasalahan baik pro maupun kontra. Pembagian subkelompok berdasarkan deretan meja tersebut menghasilkan dampak yang negatif. Fakta tersebut terlihat saat diskusi dilakukan masih banyak siswa yang ribut dan menggantungkan diri terhadap satu teman kelompoknya sehingga tujuan pembelajaran aktif dan bermakna belum didapatkan. Gambar 1 membuktikan adanya kendala yang dimaksud.

Faktor pendukung yang menyebabkan siswa kurang aktif ditinjau dari penataan posisi duduk yang kurang nyaman. Setiap meja ada anggota yang terdiri dari 6-7 anak sehingga menyebabkan beberapa anggota tidak dapat ikut berkontribusi. Setelah diskusi selesai setiap kelompok pro dan kontra menentukan siapa saja yang mewakili berdebat di depan kelas dengan menunjuk perwakilan dari tiap subkelompok yang ada. Pemilihan perwakilan dalam pelaksanaan debat yang dilakukan menimbulkan perasaan ragu pada kebanyakan siswa sehingga ketua tiap subkelompok sering diminta maju sedangkan anggota yang lainnya enggan untuk mewakili.

Pelaksanaan debat dilaksanakan setelah mendapatkan perwakilan sebagai juru bicara yang ditentukan sebelumnya. Perwakilan tiap kelompok pro dan kontra terdiri dari empat siswa yang berdebat di depan kelas dengan posisi berdiri. Debat berlangsung lancar dengan semestinya. Masalah pertama yang ditemukan dalam pelaksanaan debat adalah sulitnya mengimplementasikan model penataan posisi duduk yang relevan dengan prosedur menurut Silberman (2006) karena meja belajar siswa

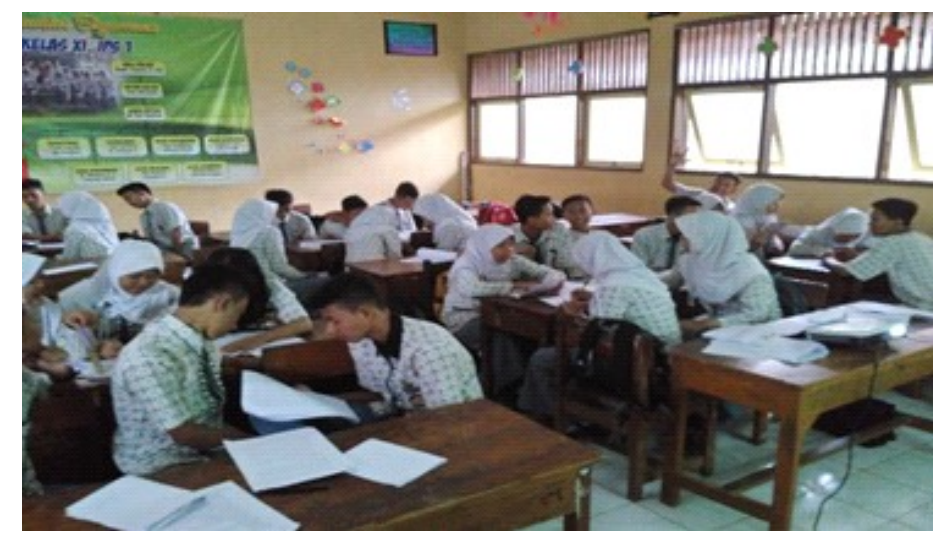

Gambar 1 Diskusi Kelompok Pertemuan Pertama 
berukuran besar. Apabila dipaksakan berakibat pada berkurangnya waktu pembelajaran. Masalah kedua terjadi karena dalam pelaksanaan tersebut perwakilan siswa masih belum mampu mempertahankan argumennya dengan baik. Hal tersebut terjadi karena masih sulit mengadakan hubungan kerja sama atau timbal balik dengan teman yang mendapatkan posisi yang sama sehingga kadang debat terhenti sebentar. Keadaan tersebut semakin membuat penerapan metode debat aktif kurang efektif karena sebagian besar siswa tidak memperhatikan, bergurau, dan kurang aktif dalam menanggapi debat yang dilakukan antarkelompok di depan kelas. Mengetahui keadaan tersebut guru mencoba memancing siswa untuk menanggapi debat yang terjadi, namun hanya sedikit siswa yang mau memberikan respon. Pemahaman materi yang masih kurang menyebabkan siswa memberikan respon ala kadarnya, sehingga dalam pertemuan pertama perlu diadakan pengkajian ulang atau evaluasi agar penerapan metode debat aktif dapat berjalan dengan efektif. Pertemuan pertama diakhiri dengan tanggapan dan kesimpulan yang dilakukan oleh guru.

\section{Tingkat Keaktifan Siswa Pertemuan Pertama}

Tahap selanjutnya setelah melakukan observasi adalah menganalisis data yang diperoleh dari lembar keaktifan siswa untuk mengetahui tingkat keaktifan siswa. Tingkat keaktifan siswa tersebut digunakan sebagai dasar untuk mengetahui efektif atau tidaknya penerapan metode debat aktif dalam pembelajaran geografi pada pertemuan pertama. Berdasarkan analisis data diperoleh hasil seperti pada Gambar 2.

Gambar 2 menunjukkan persentase penilaian keaktifan siswa pada pertemuan pertama. Perhitungan analisis dihitung dengan rumus deskripsi persentase dan dikonsultasikan dengan kriteria menurut Ridwan (2015). Hasil analisis data tingkat keaktifan siswa kelas XI IS 1 dalam aspek yang berupa kehadiran dikategorikan sangat baik. Keseriusan dalam mengikuti kegiatan pembelajaran dikategorikan baik. Partisipasi individu dalam kelompok dikategorikan baik. Diskusi dan debat dalam kelas dikategorikan sangat baik. Keseriusan dan ketepatan waktu mengumpulkan tugas sangat baik. Berdasarkan perhitungan rata-rata dari semua aspek mendapatkan hasil sebesar $81,6 \%$ sehingga dikategorikan baik.

\section{Penerapan Metode Debat Aktif Pembelajaran Geografi Pertemuan Kedua} Pertemuan kedua dilakukan selama 105 menit seperti pertemuan sebelumnya. Dalam tahap ini, guru mengalokasikan penjelasan materi dan tanya jawab selama 45 menit pada Kompetensi Dasar (KD) yang sama dengan materi pembangunan berwawasan lingkungan, pembangunan berkelanjutan, dan pemanfaatan lingkungan dalam pembangunan. Guru masih menggunakan metode yang sama berbantu media bernama iSpring Suite untuk mendukung penyampaian materi tersebut. Media tersebut

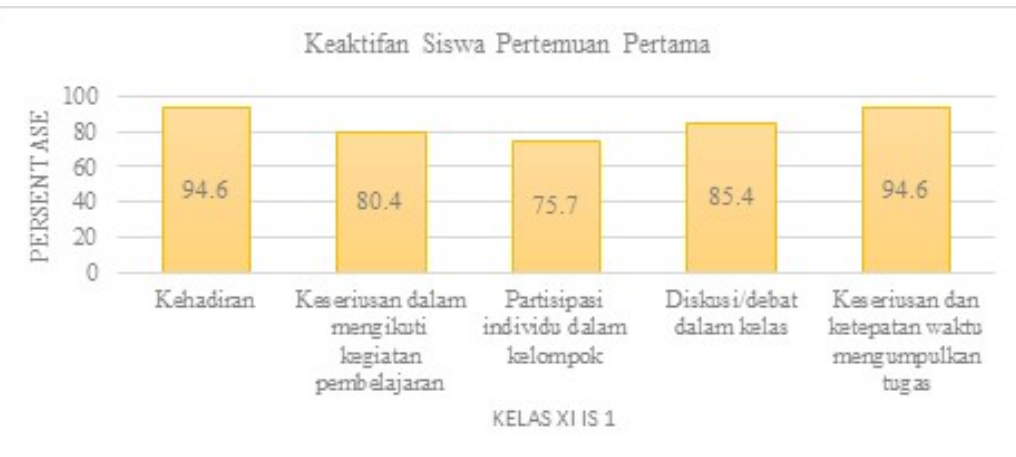

Gambar 2 Keaktifan Siswa Kelas XI IS 1 Pertemuan Pertama 
sengaja digunakan karena mudah dimanfaatkan dan dapat diintegrasikan dengan media lain serta tampilannya dapat menarik siswa. Belajar dari pengalaman sebelumnya guru lebih intens dan singkat dalam melakukan tanya jawab dengan siswa. Guru akan memberikan pertanyaan di sela-sela menjelaskan materi. Setelah sesi tanya jawab selesai guru menjelaskan dan membagikan artikel masalah kontroversial yang akan didebatkan, yaitu "Ganjar, Karimunjawa perlu dibangun pelabuhan besar" serta menampilkan videonya. Cara tersebut ternyata sudah lebih baik tetapi masih perlu peninjauan ulang agar kegiatan yang dilakukan tidak memakan banyak waktu. Hal ini disebabkan karena video yang digunakan berdurasi 4 menit. Meskipun demikian, akibat dari cara tersebut pemahaman siswa dapat meningkat daripada sebelumnya. Usai kegiatan itu, guru membagi siswa menjadi dua kelompok besar (pro dan kontra) disertai subkelompok. Pembagian sub tiap kelompok pro dan kontra berbeda dengan pertemuan pertama sehingga dibagi menjadi empat sub berdasarkan deretan meja. Sebelum kegiatan debat di depan kelas dimulai, guru mempersilahkan tiap subkelompok mendiskusikan kembali terkait artikel yang telah dibagikan selama 10 menit. Pembagian subkelompok yang jumlahnya lebih besar menghasilkan dampak lebih baik daripada sebelumnya. Anggota kelompok yang terdiri dari 4-5 orang lebih mudah dalam berperan di dalamnya. Namun sangat disayangkan dalam kegiatan diskusi masih ada siswa yang ribut dan menggantungkan diri terhadap satu teman kelompoknya meskipun jumlahnya berkurang dari sebelumnya, seperti terlihat pada Gambar 3.

Penataan posisi duduk masih sama seperti sebelumnya sehingga terlihat kurang nyaman. Setelah diskusi selesai setiap kelompok pro dan kontra menentukan siapa saja yang mewakili berdebat di depan kelas dengan menunjuk perwakilan dari tiap subkelompok yang ada. Pemilihan perwakilan dalam pelaksanaan debat yang dilakukan sudah berubah daripada sebelumnya, sehingga ketua tiap subkelompoklah yang menentukan. Pelaksanaan debat dilaksanakan setelah mendapatkan perwakilan sebagai juru bicara yang terdiri dari empat siswa untuk berdebat di depan kelas. Debat berlangsung lancar dengan didukung peran guru dalam menggunakan strategi reward and punishment sehingga siswa lebih aktif. Pelaksanaan debat pada pertemuan kedua lebih baik daripada sebelumnya karena siswa mampu mempertahankan argumennya dengan baik ditambah dengan kerja sama solid dan timbal balik antarkelompok. Namun disayangkan dalam pelaksanaan ini masih ada sebagian kecil siswa tidak memperhatikan dan kurang aktif dalam menanggapi debat. Pertemuan kedua diakhiri dengan tanggapan dan kesimpulan yang dilakukan oleh guru.

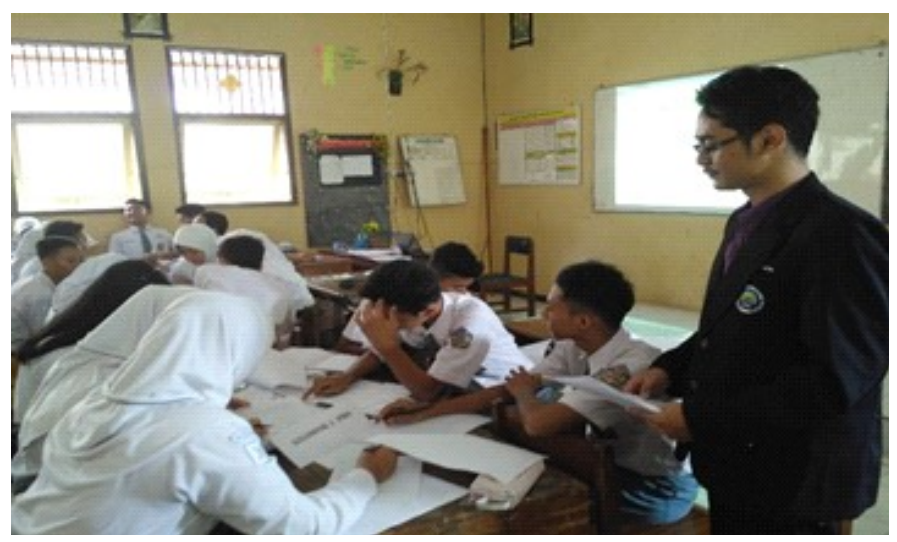

Gambar 3 Diskusi Kelompok Pertemuan Kedua 
Tingkat Keaktifan Siswa Pertemuan Kedua

Tahap selanjutnya sebagaimana pertemuan pertama adalah menganalisis data yang diperoleh berdasarkan keaktifan siswa, selanjutnya dihitung sebagaimana pertemuan pertama. Keaktifan siswa pada pertemuan kedua terjadi berbagai peningkatan dalam aspek penilaian yang telah ditentukan sebelumnya.

Gambar 4 menunjukkan adanya perbedaan persentase keaktifan siswa pada pertemuan kedua pada semua aspek. Perhitungan analisis dihitung sebagaimana pertemuan sebelumnya. Hasil analisis data tingkat keaktifan siswa kelas XI IS 1 dalam aspek yang berupa kehadiran dikategorikan sangat baik. Keseriusan dalam mengikuti kegiatan pembelajaran dikategorikan sangat baik. Partisipasi individu dalam kelompok dikategorikan baik. Diskusi dan debat dalam kelas dikategorikan sangat baik. Keseriusan dan ketepatan waktu mengumpulkan tugas sangat baik. Berdasarkan perhitungan rata-rata dari semua aspek terdapat peningkatan sehingga hasil akhir diperoleh sebesar 91\% (kategori sangat baik).

\section{Penerapan Metode Debat Aktif}

\section{Pembelajaran Geografi Pertemuan Ketiga}

Pertemuan ketiga dilakukan dengan waktu yang sama. Pembelajaran dimulai dengan penjelasan materi menganalisis resiko lingkungan hidup dalam pembangunan selama 40 menit pada Kompetensi Dasar (KD). Guru menyampaikan materi menggunakan cara yang mirip pada pertemuan kedua. Pertemuan ketiga menunjukkan bahwa keaktifan siswa dalam pembelajaran meningkat secara signifikan dinilai dari antusiasme dan keterlibatan dalam tanya jawab. Selanjutnya guru memilih tema dan menjelaskan masalah kontroversial dengan judul "BATAN akan bangun PLTN di Bangka dan Jepara". Penyampaian materi masih menggunakan metode dan media sama seperti pertemuan kedua, meskipun dalam pemilihan konten video berdurasi sekitar 4 menit. Penggunaan cara tersebut menghasilkan dampak positif pada pembelajaran yang berlangsung. Guru dan siswa dapat melakukan interaksi dan timbal balik dalam memahami materi yang disampaikan maupun dalam sesi tanya jawab. Usai kegiatan guru membagi siswa menjadi dua kelompok besar (pro dan kontra) disertai subkelompok dengan cara yang sama seperti pertemuan kedua. Kendala dalam kegiatan diskusi ini masih saja ada sebagian kecil siswa tidak aktif dalam kelompoknya, bahkan ada siswa yang bercanda dengan siswa yang lain sehingga mengganggu konsentrasi kelompok lainnya.

Penataan posisi duduk dalam tiap sub kelompok pada dasarnya menjadi kendala sejak awal penelitian. Mengatasi permasalahan tersebut guru berusaha fleksibel dalam mengaturnya selama tujuan pembelajaran didapatkan. Usai diskusi dengan tiap subkelompoknya, dilanjutkan pelaksanaan debat yang dilakukan setelah mendapatkan perwakilan sebagai juru bicara yang berjumlah 4 siswa untuk berdebat

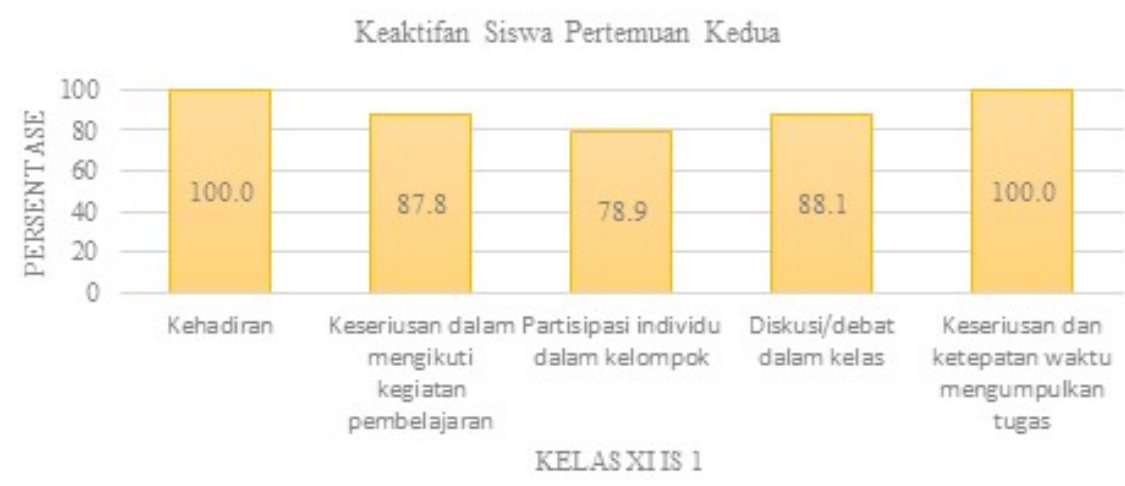

Gambar 4 Keaktifan Siswa Kelas XI IS 1 Pertemuan Kedua 


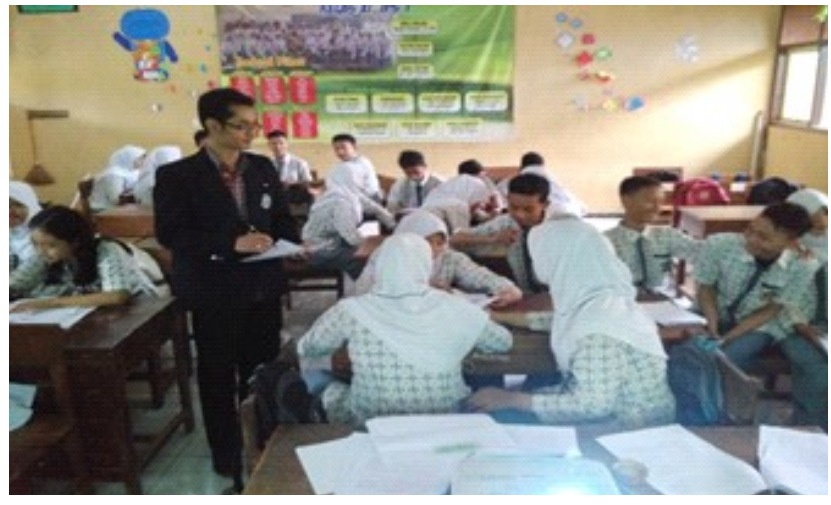

Gambar 5 Diskusi Kelompok Pertemuan Ketiga

di depan kelas. Debat berlangsung dengan lancar dan dalam pelaksanaannya siswa sudah mampu mempertahankan argumennya. Hubungan kerja sama yang erat sudah terjalin dengan teman sekelompoknya. Walaupun masih ada sebagian kecil siswa tidak memperhatikan dan kurang aktif dalam menanggapi debat. Guru berperan dalam kelancaran pelaksanaan debat dengan menggunakan strategi reward and punishment. Reward diberikan dengan memberikan pujian, applause dan nilai keaktifan. Pemberian punishment diberikan kepada siswa yang tidak memperhatikan dan kurang aktif dalam menanggapi debat.

\section{Tingkat Keaktifan Siswa Pertemuan Ketiga}

Menganalisis data yang diperoleh berdasarkan keaktifan siswa dilakukan sebagaimana pertemuan sebelumnya. Keaktifan siswa pada pertemuan ketiga menunjukkan terjadinya penurunan dalam semua aspek dibandingkan dengan pertemuan kedua. Hasil analisis data yang diperoleh ditunjukkan seperti Gambar 6.

Berdasarkan Gambar 6 menunjukkan persentase penilaian keaktifan siswa pada pertemuan ketiga. Perhitungan analisis menggunakan prosedur sesuai pertemuan sebelumnya sehingga hasil analisis data tingkat keaktifan siswa kelas XI IS 1 dalam aspek yang berupa kehadiran dikategorikan sangat baik, keseriusan dalam mengikuti kegiatan pembelajaran dikategorikan sangat baik, partisipasi individu dalam kelompok dikategorikan baik, diskusi dan debat dalam kelas dikategorikan sangat baik, keseriusan dan ketepatan waktu mengumpulkan tugas sangat baik. Berdasarkan perhitungan rata- rata dari semua aspek terjadi penurunan sehingga hasil akhir sebesar $86,8 \%$ yang dikategorikan sangat baik.

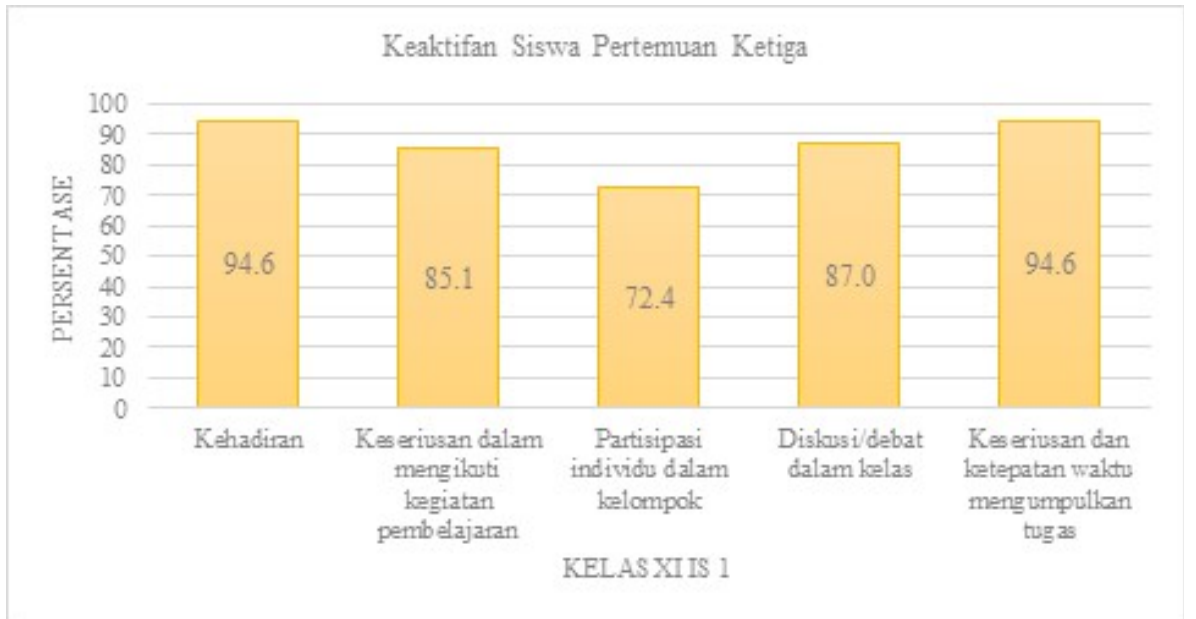

Gambar 6 Keaktifan Siswa Kelas XI IS 1 Pertemuan Ketiga 


\section{Pembahasan}

\section{Efektivitas Penerapan Metode Debat Aktif} pada Pembelajaran Geografi

Hasil penelitian sebelumnya sangat berpengaruh dalam usaha menerapkan metode debat aktif dalam pembelajaran geografi. Penerapan metode tersebut dimaksudkan untuk menguji efektivitas dalam pembelajaran geografi karena belum terdapat hasil penelitian dalam bidang ini. Menurut Suryasubrata (1990) efektivitas adalah tindakan atau usaha yang membawa hasil. Hasil yang dimaksudkan adalah terjadi perubahan siswa lebih aktif dalam kegiatan pembelajaran.

Metode debat aktif terbukti efektif digunakan dalam pembelajaran geografi. Indikator efektivitas tersebut adalah semakin meningkatnya keaktifan siswa dan interaksi guru dari pertemuan pertama hingga pertemuan ketiga dibandingkan keadaan sebelumnya karena sebelumnya guru menggunakan metode ceramah dan diskusi yang tidak membuat siswa aktif. Fakta yang terjadi relevan dengan pendapat Aunurrahman (2009) menyatakan bahwa pembelajaran yang efektif ditandai dengan terjadinya proses belajar dalam diri siswa. Seseorang dikatakan telah mengalami proses belajar apabila di dalam dirinya telah terjadi perubahan, dari tidak tahu menjadi tahu, dari tidak mengerti menjadi mengerti, dan sebagainya.

Hasil penelitian menunjukkan bahwa persentase keaktifan pertemuan pertama sebesar $81,6 \%$ (kategori baik). Pertemuan kedua terjadi peningkatan sebesar $9,4 \%$ menjadi $91 \%$ (kategori sangat baik), yang antara lain disebabkan oleh meningkatnya persentase pada aspek kehadiran sebesar 5,4\%, keseriusan dalam mengikuti kegiatan pembelajaran sebesar $7,4 \%$, partisipasi individu dalam kelompok sebesar 3,2\%, diskusi dan debat dalam kelas sebesar 2,7\%, dan keseriusan dan ketepatan waktu mengumpulkan tugas sebesar $5,4 \%$. Persentase keaktifan siswa pada pertemuan ketiga sebesar $86,8 \%$ (kategori sangat baik) atau menurun sebesar $4,4 \%$ yang disebabkan menurunnya persentase pada aspek kehadiran sebesar 5,4\%, keseriusan dalam mengikuti kegiatan pembelajaran sebesar $2,7 \%$, partisipasi individu dalam kelompok sebesar $6,5 \%$, diskusi dan debat dalam kelas sebesar $1,1 \%$, serta keseriusan dan ketepatan waktu mengumpulkan tugas sebesar 5,4\%. Berdasarkan rata-rata persentase dari semua pertemuan maka diperoleh hasil sebesar $86,4 \%$ sehingga dapat disimpulkan bahwa efektivitas penerapan metode debat aktif dalam pembelajaran geografi adalah sangat baik. Faktor pendukung menunjang efektivitas penerapan metode debat aktif adalah penggunaan media iSpring Suite dan strategi reward and punishment sehingga siswa tertarik dalam mengikuti pembelajaran sebagai akibat mendapatkan pengalaman berbeda daripada sebelumnya.

Keberhasilan dalam penelitian ini masih meninggalkan beberapa permasalahan dalam penerapan metode debat. Fakta permasalahan tersebut dapat diketahui mulai dari pertemuan pertama sampai ketiga yang disebabkan oleh kelemahan yang ada pada metode tersebut. Merujuk Shoimin (2014) maka kelemahan tersebut dapat dijelaskan oleh beberapa hal. Pertama, waktu yang dibutuhkan banyak dimana dari penelitian ini diketahui bahwa dalam penerapan membutuhkan waktu yang lebih banyak daripada penjelasan materi. Kedua, materi yang didapat sedikit yaitu sebagai efek negatif dari penerapan metode debat aktif dimana guru mengalokasikan waktu penjelasan materi hanya 30-45 menit saja sehingga materi yang didapatkan sedikit terutama jika tidak dibarengi kemandirian siswa untuk belajar dirumah akan membuat pembelajaran tidak efektif. Masalah ini juga menjadi penyebab kelemahan lain yang muncul yaitu lebih sedikit ide yang muncul saat pelaksanaan karena manajemen waktu yang kurang efektif. Ketiga, Kondisi akan monoton jika tidak menggunakan media pembelajaran. Penerapan metode debat aktif pada dasarnya tidak boleh dipisahkan dalam menggunakan media. Masalah tersebut akan muncul bila tidak menggunakan media, misalnya tingkat daya serap siswa dalam memahami 
materi debat akan menurun sehingga akan berakibat pada efektivitas dalam pelaksanaannya.

Kelemahan lain metode debat aktif didukung oleh Marsidjo (1990) yang lebih menekankan pada unsur psikologis. Kelemahan tersebut diantaranya: Pertama, penerapan metode tersebut menyebabkan terjadi kompetisi siswa untuk menang dalam debat. Masalah tersebut wajar terutama kalau pertama kali diterapkan, tetapi kompetisi tersebut dapat diambil manfaatnya selama kompetisi tidak bermaksud untuk saling menjatuhkan. Masalah tersebut apabila dinilai menganggu penerapan metode debat aktif dapat dicegah dengan peran guru dalam menjelaskan bahwa tujuan dari debat ini bukan memutuskan pihak mana yang menang, melainkan untuk melatih siswa untuk demokratis, menerima perbedaan dan menghasilkan kesimpulan bersama. Kedua, terlalu melibatkan emosi dan menyebabkan kesan yang salah terhadap persepsi tiap siswa. Masalah ini sekali lagi masih berhubungan dengan urusan psikologis sehingga dapat dicegah dengan cara yang sama seperti sebelumnya. Ketiga, membatasi adanya partisipasi kelompok, kecuali dibarengi dengan diskusi. Kelemahan tersebut sebenarnya masih perlu ditelaah lebih jauh karena pada dasarnya metode debat aktif tidak pernah membatasi partisipasi kelompok malah sebaliknya metode tersebut memberikan keleluasaan untuk mendukung pembelajaran aktif. Partisipasi kelompok bisa saja terbatas karena tekanan dari kelompok lain yang berbeda pendapat atau disebabkan oleh waktu yang kurang. Diskusi memang digunakan sebagai langkah awal untuk menyamakan persepsi antaranggota kelompok tetapi tidak pernah menjadi penghalang untuk berpartisipasi dalam pelaksanaan debat.

Berdasarkan permasalahan yang dialami dalam penerapan metode debat aktif maka sudah sepatutnya terdapat strategi yang dapat digunakan untuk mengoptimalkan penerapannya. Strategi yang diajukan terdiri dari pengaturan estimasi waktu, pembagian subkelompok secara terencana, penggunaan media pembelajaran, pemilihan materi debat, pengaturan posisi duduk, menerapkan strategi reward and punishment.

\section{Strategi Mengoptimalkan Penerapan Metode Debat Aktif}

Pengaturan Estimasi Waktu

Permasalahan utama dalam penerapan metode debat aktif adalah membutuhkan waktu yang lama. Penelitian ini menunjukkan bahwa penerapan metode debat aktif bermasalah yang disebabkan oleh faktor-faktor tertentu, seperti berikut. Pertama, penyampaian materi pelajaran. Berdasarkan fakta yang ditemukan menunjukkan bahwa penyampaian materi pembelajaran yang dilakukan guru dalam pertemuan 1-3 memakan waktu antara 30-45 menit dan bisa bertambah jika guru melakukan sesi tanya jawab. Waktu yang dibutuhkan sebesar itu akan mempengaruhi efektivitas dalam penerapan metode debat aktif sehingga metode ini bisa dikatakan kurang cocok jika diterapkan untuk mata pelajaran yang tiap satu pertemuan hanya mendapatkan jatah waktu sebesar 30-45 saja. Kedua, penyampaian materi debat, merupakan prosedur yang wajib dijalankan sebelum pelaksanaan debat. Prosedur tersebut bisa menyita waktu lama jika siswa belum memahami materi yang disampaikan guru, apalagi jika ada sesi tanya jawab yang berlangsung lama. Ketiga, pembagian kelompok beserta diskusi kecilnya, kegiatan ini tidak bisa dipisahkan sebelum melaksanakan debat sehingga dalam keadaan ini guru wajib memberi batas waktu yang mencukupi dan mengawasi siswa dengan sebaik-baiknya. Keempat, pelaksanaan debat. Pelaksanaan debat ini dimulai dari pemilihan peserta yang mewakili debat, pelaksanaan debat di depan kelas dan adanya debat yang melibatkan seluruh anggota kelompok lain. Kegiatan ini merupakan inti dari penerapan metode debat aktif sehingga wajar jika memakan waktu yang lebih lama daripada langkah sebelumnya. 
Permasalahan tersebut penting sekali di atasi sehingga strategi yang tepat adalah pengaturan estimasi waktu atau mengelola waktu yang wajib dilakukan dalam pembelajaran. Menurut Sandra \& Djalali (2013) manajemen waktu merupakan perencanaan, pengorganisasian, pengetatan dan pengawasan produktivitas waktu. Dari pendapat tersebut maka disimpulkan bahwa manajemen waktu memiliki indikator dalam menunjang efektivitas waktu yaitu sebagai berikut. Pertama, perencanaan, perencanaan dalam pembelajaran bertujuan untuk mengetahui berbagai tindakan apa saja yang harus dilakukan untuk mencapai tujuan yang diinginkan guru. Perencanaan dalam pembelajaran dapat dilakukan dengan membuat silabus dan Rencana Pelaksanaan Pembelajaran. Kedua, pengorganisasian adalah suatu langkah yang digunakan untuk menghubungkan antara tindakan yang dilakukan dengan estimasi waktu yang telah ditentukan agar mendukung perencanaan pembelajaran. Pengorganisasian yang baik akan berdampak pada efektivitas pembelajaran. Ketiga, pengetatan dan pengawasan produktivitas waktu, indikator ini dapat berguna sebagai alat kontrol untuk kedua indikator agar pembelajaran yang berlangsung sesuai dengan yang direncanakan sebelumnya. Indikator tersebut juga bermanfaat sebagai dasar untuk melakukan evaluasi dalam pelaksanaan pembelajaran. Pengetatan dan pengawasan produktivitas waktu akan lebih akurat jika dibantu oleh observer atau evaluator yang mengikuti pembelajaran yang dilaksanakan oleh guru. Juliasari \& Kusmanto (2016) menunjukkan bahwa manajemen waktu memiliki pengaruh besar terhadap prestasi belajar. Hasil penelitian Rahayu, Ansofino dan Sumarni (2014) menunjukkan bahwa waktu belajar berpengaruh positif dan signifikan terhadap hasil belajar siswa. Ayunthara (2016) membuktikan bahwa terdapat pengaruh positif dan signifikan manajemen waktu terhadap prestasi belajar

Berdasarkan permasalahan di atas maka strategi yang dapat digunakan untuk mengefektikan waktu dalam penerapan metode debat aktif adalah sebagai berikut. Pertama, penggunaan media pembelajaran. Penggunaan media pembelajaran memegang peranan penting untuk mengoptimalkan waktu pembelajaran. Terdapat berbagai macam media pembelajaran yang dapat dimanfaatkan agar pemahaman siswa meningkat khususnya pada materi geografi atau materi debat. Kedua, memilih materi debat yang singkat, jelas dan padat. Pemilihan materi debat selain mensyaratkan agar memancing opini pro maupun kontra tetap saja harus memperhatikan batasan isinya. Jika materi terlalu banyak siswa akan membutuhkan banyak waktu untuk membaca dan menganalisisnya. Materi debat yang singkat, jelas, dan padat perlu digunakan agar menghemat waktu. Cara lain agar dapat menghemat waktu adalah guru membagikan materi atau link website serta menyuruh siswa untuk mempelajari di rumah. Ketiga, pembagian kelompok lebih awal sudah direncanakan. Strategi tersebut patut digunakan mengingat dalam hasil penelitian siswa masih ada yang enggan berkelompok dengan yang lain. Hal ini akan memakan waktu lama sehingga akan berkuranglah jatah waktu dalam pelaksanaan debat.

\section{Pembagian Subkelompok Secara Terencana} Pembagian kelompok memiliki peranan penting dalam mendukung kelancaran dalam penerapan metode debat aktif. Permasalahan yang dialami pada pertemuan awal hingga terakhir menunjukkan akibat dari pembagian anggota dalam tiap subkelompok dilakukan secara sederhana sehingga menimbulkan dampak negatif. Dampak tersebut dibuktikan dalam penerapan metode debat aktif masih banyak siswa yang enggan berpartisipasi dan sering terlihat ribut. Hal ini disebabkan ada beberapa siswa yang mendominasi dalam kerja kelompok atau kemampuan siswa yang kurang memahami tujuan pembelajaran sehingga terlihat saling menggantungkan. Masalah tersebut mengakibatkan kegiatan belajar aktif tidak sesuai dengan tujuannya. 
Pembagian subkelompok yang memperhatikan kompetensi dari masing-masing siswa tersebut perlu diperhatikan agar antara satu siswa dengan yang lain dapat turut berkontribusi aktif dalam pelaksanaan debat. Dari permasalahan di atas maka strategi yang disarankan adalah membagi subkelompok secara heterogen dengan berdasarkan nilai tes atau persentase keaktifan tiap individu. Cara tersebut dinilai memiliki andil dalam meningkatkan kemampuan tiap siswa dalam pembelajaran karena dalam pembagian sub terdiri dari siswa yang memiliki variasi kemampuan atau keaktifan mulai dari tingkatan tinggi, sedang dan rendah sehingga siswa dapat bekerja sama dan saling melengkapi dalam perannya. Strategi tersebut sejalan dengan penelitian Adodo \& Agbayewa (2011) yaitu bahwa pengelompokan siswa berdasarkan kemampuan kognitif dapat bermanfaat untuk meningkatkan prestasi siswa sedangkan manfaat bagi guru adalah memudahkan mengajar, mengendalikan proses pemberian instruksi dan memberikan penguatan kepada siswa berdasarkan prestasinya. Pembagian subkelompok secara terencana sudah dilakukan pada pertemuan kedua meskipun guru menggunakan cara lain yaitu berdasarkan deret bangku, mengingat pada pertemuan pertama terdapat permasalahan akibat pembagian secara mendadak sehingga hasil keaktifan siswa terbukti lebih baik.

\section{Penggunaan Media Pembelajaran}

Media pembelajaran diperlukan sebagai sarana komunikasi dan membantu guru dalam mengajar sehingga apa saja yang disampaikan akan lebih mudah dipahami oleh siswanya. Penerapan metode debat aktif membutuhkan media agar pembelajaran tidak terkesan monoton sebagaimana diungkapkan oleh Shoimin (2014) agar siswa tidak bosan dalam mengikuti aktivitas pembelajaran. Mengingat perma-salahan pada pertemuan pertama bahwa guru awalnya menjelaskan materi tanpa media sehingga menyebabkan siswa tidak paham. Berdasarkan kelemahan tersebut maka guru disarankan untuk menggunakan media pembe-lajaran berbasis komputer sehingga berdampak positif dalam pembelajaran. Penelitian yang relevan membuktikan bahwa media pembelajaran berbasis komputer berperan dalam mendukung peningkatan motivasi dan hasil belajar (Halidi, Husain \& Saehana, 2015; Hanim, Sumarmi \& Amirudin, 2016; Seroja \& Gultom, 2015; Utami, 2014; dan Yulia, 2013) sehingga diharapkan dalam penerapan debat aktif media berbasis komputer tidak hanya digunakan sebagai bentuk formalitas mengajar saja tetapi dapat bermanfaat untuk mendapatkan dampak positif dalam kegiatannya.

Penggunaan iSpring Suite dan media cetak sebagai media dimaksudkan untuk mendukung penerapannya sehingga siswa lebih tertarik dan dapat menambah pemahaman. Penelitian oleh Suprapti (2015) dan Suprapti (2016) menunjukkan terjadi peningkatan hasil belajar setelah menggunakan iSpring Suite sehingga direkomendasikan untuk digunakan. Penggunaan media komputer tersebut wajib mempertimbangkan konten yang singkat dan jelas terutama berupa teks dan gambar. Teks dan gambar yanng singkat dan jelas dapat memudahkan siswa untuk memahami materi yang disampaikan oleh guru. Pengaturan tampilan yang menarik juga perlu dipertimbangkan sehingga siswa dapat lebih fokus dan tertarik untuk mengikuti kegiatan pembelajaran. Mempertimbangkan durasi atau waktu yang tepat juga penting apabila media berbasis komputer tersebut hendak diintegrasikan dengan media lain yang dapat membantu dalam memperjelas materi seperti video dan audio. Semakin singkat durasinya akan berpengaruh terhadap estimasi waktu dalam pelaksanaan debat. Meskipun efektivitasnya bisa berbeda, misalnya hasil penelitian pada pertemuan pertama konten video yang diintegrasikan dengan iSpring Suite memiliki durasi 3 menit tidak lebih baik hasilnya daripada pertemuan kedua yang durasinya 4 menit. Sementara itu, pertemuan ketiga yang durasinya sama dengan pertemuan kedua hasilnya lebih buruk sehingga keahlian dalam pengelolaan 
media pembelajaran juga berpengaruh dalam efektivitas penerapannya.

\section{Pemilihan Materi Debat}

Pemilihan materi debat wajib dipertimbangkan terlebih dahulu untuk menunjang penerapan metode debat aktif dalam pembelajaran di kelas. Materi yang tepat tidak hanya membuat siswa tertarik tetapi dapat berguna untuk merangsang siswa agar aktif dalam kegiatan pembelajaran. Sejatinya guru sudah baik dalam memilih materi dalam penelitian yang dilakukan, meski harus ada sedikit perbaikan agar materi debat lebih ringkas terutama pada pertemuan pertama sebanyak 2 lembar. Pemilihan materi debat yang baik dapat ditinjau dengan syarat tertentu agar layak digunakan. Persyaratan yang dikemukakan agar materi debat dapat mempengaruhi lancar atau tidaknya pelaksanaan debat adalah sebagai berikut. Pertama, materi yang digunakan dapat menggiring opini siswa untuk bersikap pro dan kontra. Materi yang dipilih disarankan untuk dianalisis terlebih dahulu oleh guru agar tidak terjadi adanya ketimpangan atau opini yang bersifat berat sebelah. Opini yang dimaksud berarti materi yang digunakan sekilas membatasi atau menggiring opini siswa pada satu sisi semata sehingga mengakibatkan kegiatannya tidak sesuai dengan tujuan. Kedua, materi yang digunakan harus dikiwarikan (ter update) dan konkret sehingga mendukung pembelajaran berbasis kontekstual. Materi terkiwarikan adalah materi yang bersifat baru dan populer sehingga siswa akan lebih tertarik dalam mengkaji isi materi debat tersebut. Pemilihan materi tersebut juga dapat bermanfaat dalam menghemat waktu dalam pelaksanaan debat karena materi yang bersifat demikian tentunya siswa sudah mendapatkan pemahaman awal yang baik sehingga mengurangi intensitas tanya jawab. Materi yang konkret menunjukkan bahwa materi yang digunakan merupakan sebuah fakta yang terjadi di lapangan sehingga dapat bermanfaat untuk menunjang adanya pembelajaran secara konstekstual. Ketiga, materi yang ringkas dan jelas. Materi yang memenuhi persyaratan ketiga perlu digunakan agar siswa bisa lebih mudah dalam memahami isi dari materi debat, selain itu materi yang ringkas dan jelas dapat berfungsi dalam menghemat waktu siswa dalam beraktivitas. Terbukti pada pertemuan kedua sebanyak 1 lembar dan pertemuan ketiga 1,5 lembar berdampak pada keaktifan siswa yang lebih baik daripada pertemuan pertama.

\section{Pengaturan Posisi Duduk}

Pengaturan posisi duduk dalam persiapan maupun pelaksanaan dalam metode debat aktif perlu diperhatikan agar siswa mampu beraktivitas dan berperan baik dalam pembelajaran yang dilaksanakan. Selain itu dengan strategi tersebut diharapkan dapat memberikan dampak positif terhadap siswa dalam kegiatannya. Partin (2012) mengemukakan bahwa posisi tempat duduk siswa dapat berpengaruh terhadap prestasi belajar. Hasil penelitian Perkins \& Wieman (2005) menunjukkan posisi tempat duduk menentukan partisipasi siswa dalam belajar di kelas. Hasil penelitian Montello (1988) menguatkan bahwa posisi tempat duduk siswa berpengaruh terhadap partisipasi dalam pembelajaran. Pendapat di atas menguatkan bahwa posisi tempat duduk memiliki dampak signifikan untuk menunjang efektivitas pembelajaran dan berpengaruh positif bagi siswa tersebut.

Fakta yang ditemukan dalam hasil penelitian menunjukkan bahwa pengaturan posisi duduk yang dilakukan guru masih sederhana atau secara tradisional. Hal ini berakibat pada ketidaknyamanan siswa dalam aktivitas pembelajaran yang dilakukan. Ketidaknyamanan tersebut dapat diketahui dari beberapa siswa yang berusaha mengubah kursinya berkali-kali sehingga menimbulkan kegaduhan dan mengganggu siswa lain. Selain itu, dengan posisi duduk tersebut akan mempengaruhi pemahaman dan tingkat partisipasi dalam pelaksanaan debat di depan kelas. Strategi yang digunakan dalam mengatasi masalah tersebut adalah menyusun tata letak kelas yang menunjang kegiatan 
belajar aktif berdasarkan dengan bentuk gaya U (Silberman, 2006). Beberapa tata letak yang bagus dan relevan digunakan untuk mendukung penerapan metode debat aktif adalah menggunakan bentuk $\mathrm{U}$ (tampak setengah lingkaran) dan bentuk modular. Bentuk tersebut diasumsikan tepat karena dalam pembentukannya tidak memakan waktu banyak daripada bentuk lainnya, mudah diterapkan, dan mempunyai kelebihan dalam bentuknya. Bentuk tersebut terdapat sela-sela yang cukup lebar sehingga membuat siswa nyaman dalam beraktivitas secara berkelompok terutama jika anggota dalam tim sebanyak 4-5 siswa atau lebih sehingga tidak mengganggu kelompok lain. Suparman (2010) mengungkapkan bahwa kelebihan dari formasi bentuk $U$ sangat tepat digunakan dalam pembelajaran yang kegiatannya berupa diskusi, presentasi, dan kerja tim. Terkait bentuk modular di atas diperkuat oleh Setiyadi \& Ramdani (2016) bahwa bentuk tersebut memudahkan terjadinya interaksi sosial

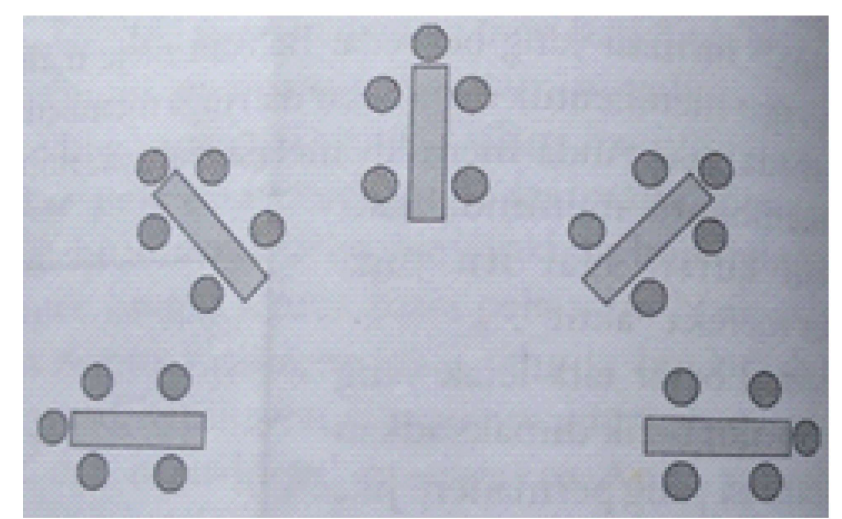

Sumber: Silberman (2006)

Gambar 7 Bentuk U setengah lingkaran antarsiswa dan guru. Selain itu bentuk modular sering digunakan pada cooperative learning yang menuntut siswa untuk aktif baik berdiskusi maupun dalam memecahkan masalah pembelajaran. Bentuk tersebut dijelaskan seperti Gambar 7 dan 8.

Kedua bentuk pada Gambar 7 dan Gambar 8 dapat digunakan untuk diskusi semata atau mendukung pelaksanaan debat jika bentuk yang dianjurkan oleh Silberman tidak dimungkinkan untuk dilaksanakan karena pertimbangan tertentu yang dialami oleh guru dalam penerapannya, misalnya karena waktu atau membutuhkan ruang kelas yang luas. Menerapkan bentuk dapat dipadukan dengan posisi juru bicara dari perwakilan masing-masing sub yang dapat berdiri atau mengambil kursi untuk duduk depan kelas. Perpaduan tersebut membuat penerapan metode debat aktif dapat berlangsung efektif dan guru dengan mudah bisa mengawasi siswa dalam beraktivitas terutama untuk memberikan penilaian dalam ranah afektif.

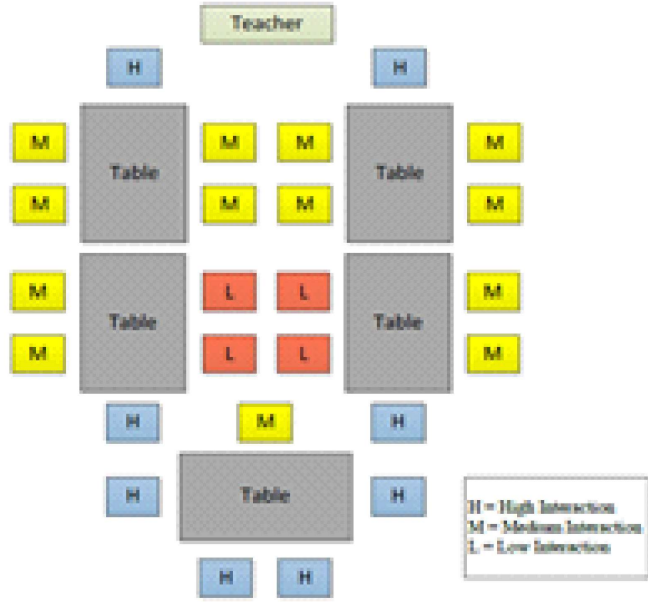

Sumber: Setiyadi \& Ramdani (2016)

Gambar 8 Bentuk Modular

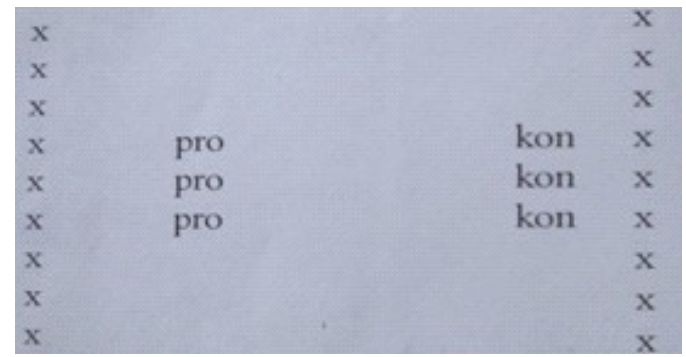

Sumber: Silberman (2006)

Gambar 9 Posisi pelaksanaan Debat Aktif 
Posisi duduk menurut Silberman (2006) dapat mudah diterapkan bagi sekolah yang tidak menggunakan meja besar di kelas atau memiliki kursi dengan meja kecil yang biasanya digunakan mahasiswa pada saat kuliah sehingga strategi ini tidak memungkinkan karena keterbatasan waktu penelitian meskipun penelitian sebelumnya sudah menguatkan. Posisi yang sesuai dengan pendapat Silberman seperti Gambar 9.

Menerapkan Strategi Reward and Punishment Siswa yang pasif dalam kegiatan pembelajaran dapat menghalangi guru untuk mewujudkan pembelajaran yang aktif dan bermakna. Metode debat aktif pada dasarnya adalah metode yang menekan siswa untuk aktif secara individu maupun kelompok sehingga membutuhkan strategi yang tepat untuk merangsang siswa untuk senantiasa aktif. Berdasarkan hasil penelitian menunjukkan bahwa penerapan metode debat aktif pada pertemuan pertama masih ada siswa yang enggan untuk berpartisipasi dalam kegiatan pembelajaran di kelas. Masalah tersebut dapat terjadi tidak lepas dari faktor peranan guru dan psikologi siswa dalam kegiatannya.

Peranan guru yang baik dalam mengatur sistem pembelajaran adalah tonggak untuk mencapai keberhasilan dalam mewujudkan tujuan. Metode debat aktif agar dapat terlaksana dengan baik maka disarankan guru menggunakan strategi reward and punishment. Reward dapat diartikan sebagai sebuah penghargaan yang diberikan guru kepada siswa karena keterlibatan siswa dalam aktivitas positif yang ditentukan. Pendapat tersebut diperkuat oleh Purwanto (2006) bahwa penghargaan dapat bermanfaat bagi siswa untuk lebih giat, memperbaiki diri, dan mempertinggi kedisiplinannya berdasarkan norma.

Punishment digunakan untuk mengimbangi adanya reward yang diberikan guru. Tindakan punisment dapat terjadi karena guru menilai siswa tidak melakukan suatu aktivitas belajar yang tidak sesuai dengan target, norma atau aturan yang telah ditetapkan. Tujuan pemberian punisment agar siswa lebih disiplin dan mau meningkatkan kompetensinya dalam pembelajaran. Pendapat tersebut diperkuat oleh Imron (2012) bahwa hukuman adalah suatu sanksi yang diterima oleh seseorang akibat dari pelanggaran aturan-aturan yang telah ditetapkan. Hukuman diberikan sebagai alat pendidik dan menyadarkan peserta didik. Penggunaan strategi reward and punishment terbukti memberikan dampak positif terutama untuk meningkatkan motivasi belajar (Azis, 2016; Sujiantari, 2016; Wulandari \& Hidayat, 2014) dan terbukti efektif meningkatkan hasil belajar siswa (Prasetiyo, 2016; Yana, Hajidin \& Safiah, 2016). Berdasarkan penjelasan tersebut maka penggunaan strategi ini sangat berperan penting dalam menunjang penerapan metode debat aktif.

Implementasi strategi reward and punishment dengan mudah dapat dipraktikkan langsung oleh guru. Guru dapat memberikan pujian, applause dan nilai tambah sebagai wujud implementasi strategi reward. Strategi punishment dapat dilakukan dengan tidak perlu memberikan nilai tambahan atau pujian. Guru dapat memberikan teguran bagi siswa yang kurang aktif bahkan mengganggu dalam kegiatan pembelajaran di kelas. Strategi tersebut terbukti pada pertemuan kedua dan ketiga. Siswa terlihat lebih tanggap, sehingga keaktifan siswa meningkat daripada pertemuan pertama. Strategi tersebut bagus digunakan agar guru mendapatkan kesan positif serta bermanfaat secara positif dalam aktivitas belajar. Ulfah, Santoso \& Utaya (2016) menyatakan bahwa kepribadian guru yang perhatian, hangat, suportif, dan pemberi semangat berdampak pada motivasi siswa sehingga dapat meningkatkan prestasi belajar.

\section{SIMPULAN DAN SARAN}

\section{Simpulan}

Berdasarkan hasil penelitian ini dapat disimpulkan bahwa metode debat aktif yang diterapkan dalam pembelajaran geografi memiliki tingkat 
efektivitas yang sangat baik. Efektivitas tersebut ditinjau dari peningkatan dalam keaktifan siswa menjadi lebih baik daripada sebelumnya. Strategi dalam penerapan perlu diimplementasikan agar semakin optimal. Strategi pengaturan estimasi waktu dapat dilakukan guru dengan membuat rencana pelaksanaan pembelajaran yang matang. Strategi pembagian subkelompok secara terencana menciptakan suasana yang kondusif dalam menunjang kelancaran dalam penerapannya. Strategi penggunaan media pembelajaran dan strategi pemilihan materi debat berguna untuk meningkatkan pemahaman siswa akan materi yang dijelaskan sekaligus memfasilitasi pelaksaan debat. Strategi pengaturan posisi duduk dapat memperlancar persiapan dan pelaksanaan metode debat aktif. Menerapkan strategi reward and punishment juga memiliki andil dalam membuat penerapan metode debat aktif karena mampu membuat siswa lebih aktif, tanggap dan leluasa sehingga perlu digunakan dalam penelitian. Selain itu hasil kajian empirik yang didukung oleh berbagai penemuan sebelumnya dapat membuktikan bahwa metode debat aktif dalam penelitian ini dapat digunakan sebagai metode yang dapat menunjang pembelajaran lebih efektif dan memiliki dampak positif.

\section{Saran}

Penerapan metode debat aktif dan strateginya dalam mengoptimalkannya terbukti membawa dampak positif dalam mendukung efektivitas pembelajaran geografi maka disarankan guru menggunakan metode tersebut sebagai alternatif yang dapat digunakan dalam pembelajaran. Guru juga dapat memadukan metode debat aktif dengan berbagai macam strategi dan media pembelajaran yang relevan dalam usaha meningkatkan efektivitasnya. Menunjang perkembangan ilmu pengetahuan maka penelitian selanjutnya dapat dilakukan pada Kompetensi Dasar (KD) geografi atau mata pelajaran yang lain sehingga semakin menguatkan hasil penelitian sebelumnya, menambah referensi dan menemukan strategi baru yang tepat agar penerapan metode debat aktif dapat diterapkan secara efektif.

\section{PUSTAKA ACUAN}

Adodo. S.O \& Agbayewa, J.O. 2011. Effect of homogenous and heterogeneous ability grouping class teaching on student's interest, attitude and achievement in integrated science. International Journal of Psychology and Counselling, 3(3), 48-54.

Aunurrahman. 2009. Belajar dan Pembelajaran. Bandung: Alfabeta

Ayunthara, A. 2016. Pengaruh Penggunaan Teknologi Informasi, Lingkungan Sekolah dan Manajemen Waktu Terhadap Prestasi Belajar Ekonomi. Jurnal Pendidikan dan Ekonomi, 5(3), 251-257.

Azis. 2016. Reward-Punishment Sebagai Motivasi Pendidikan (Perspektif Barat dan Islam). Cendekia, 14(2), 33-34.

Badan Standar Nasional Pendidikan. 2010. Paradigma Pendidikan Nasional Abad XXI. Jakarta: Kementerian Pendidikan dan Kebudayaan.

Djunadi, D.I. 2010. Efektivitas Penerapan Metode Active Debate dalam Pembelajaran Sosiologi. Jurnal Dimensia, 4(1), 61-76.

Halidi H.M, Husain, S.N \& Saehana, S. 2015. Pengaruh Media Pembelajaran Berbasis TIK Terhadap Motivasi dan Hasil Belajar IPA Siswa Kelas V SDN Model Terpadu Madani Palu. Jurnal e-Mitra Sains, 3(1), 53-60.

Hanim.F, Sumarmi \& Amirudin, A. Pengaruh Penggunaan Multimedia Pembelajaran Interaktif 
Pradika Adi Wijayanto, Sugeng Utaya \& Ach. Amirudin, Efektivitas Metode Debat Aktif Dan Strategi Penerapannya Dalam Mengoptimalkan Pembelajaran Geografi

Penginderaan Jauh Terhadap Hasil Belajar Geografi. Jurnal Pendidikan: Teori, Penelitian, dan Pengembangan, 1(4), 752-757.

Imron. A. 2012. Manajemen Peserta Didik Berbasis Sekolah. Jakarta: Bumi Aksara.

Ismail S. M. 2008. Strategi Pembelajaran Agama Islam Berbasis PAIKEM. Semarang: Rasail Media Group.

Juliasari,N. \& Kusmanto, B. 2016. Hubungan Antara Manajemen Waktu Belajar, Motivasi Belajar, dan Fasilitas Belajar dengan Prestasi Belajar Matematika Siswa SMP Kelas VIII SeKecamatan Danurejan Yogyakarta. UNION: Jurnal Pendidikan Matematika, 3(3), 405-412.

Marsidjo, N. 1990. Kapita Selekta Psikologi Pendidikan. Yogyakarta: Universitas Sanata Dharma.

Mashudi, M \& Kholis, N. 2015. Pengaruh Model Pembelajaran Aktif dengan Metode Active Debate Terhadap Hasil Belajar pada Standar Kompetensi Memperbaiki CD Player di SMKN 2 Surabaya. Jurnal Pendidikan Teknik Elektro, 04(03), 747-751.

Montello, D.R. 1988. Classroom Seating Location and Its Effect on Course Achievement, Participation, and Attitudes. Journal of Environmental Psychology, 8(0), 149-157.

Mufidah, L. 2012. Penerapan Pembelajaran Inkuiri Terbimbing dengan Program Moodle pada Materi Reaksi Redoks serta Larutan Elektrolit dan Non elektrolit untuk Meningkatkan Motivasi dan Hasil Belajar Siswa. Tesis. Malang: Pascasarjana Universitas Negeri Malang.

Nurdin, M. 2016. Penerapan Metode Debat Aktif untuk Meningkatkan Kemampuan Berdiskusi Mahasiswa dalam Pembelajaran Konsep Dasar PKn dI PGSD UPP Bone FIP UNM. Jurnal Publikasi Pendidikan, 6(1), 1-7.

Partin, R.L. 2012. Kiat Nyaman Mengajar di Dalam Kelas. Jakarta: PT. Indeks.

Perkins, K.K. \& Wieman, C.E. 2005. The Surprising Impact of Seat Location on Student Performance. The Physic Teacher, 43(1), 30-33.

Pramesswari, A.S, Widodo, W. \& Qosyim, A. 2016. Penerapan Strategi Debat Aktif untuk Melatihkan Keterampilan Berpikir Kritis pada Materi Pemanasan Global. Jurnal Pendidikan Sains, 4(3), 1-6.

Prasetiyo, H.E. 2015. Hubungan Persepsi Penerapan Metode TGT, Teknik Reward and Punishment dan Motivasi Belajar Terhadap Hasil Belajar Siswa Kelas V SDN I Ngrejo Tulungagung. Konstruktivisme, 7(2), 119-129.

Purwanto. N. 2006. Ilmu Pendidikan Teoritis dan Praktis. Bandung: Remaja Rosdakarya.

Ridwan. 2015. Skala Pengukuran Variabel-Variabel Penelitian. Bandung:Alfabeta.

Sandra, K.I \& Djalali, M.A. 2013. Manajemen Waktu, Efikasi-Diri dan Prokrastinasi. Persona Jurnal Psikologi Indonesia, 2(3), 217-222

Seroja, M. \& Gultom, I. 2015. Pengaruh Penggunaan Media Pembelajaran dan Motivasi Berprestasi Terhadap Hasil Belajar Geografi Siswa SMP Negeri Kecamatan Singkil. Jurnal Teknologi Informasi dan Komunikasi dalam Pendidikan, 2(1), 1-14.

Setiyadi, B.R \& Ramdani, S.D. 2016. Perbedaan Pengaturan Tempat Duduk Siswa pada Pembelajaran Saintifik di SMK. Journal of Mechanical Engineering Education, 1(1), 28-41.

Shoimin, A. 2014. 68 Model Pembelajaran Inovatif dalam Kurikulum 2013. Yogyakarta: AR-RUZZ MEDIA.

Silberman, M.L. 2006. Active Learning 101 Cara Belajar Siswa Aktif. Bandung: PT Nusamedia. Sudarmawanto \& Buditjahjanto, I.G.P.A. 2012. Pengaruh Model Pembelajaran Aktif dengan 
Pendekatan Active Knowledge Sharing dan Active Debate Terhadap Hasil Belajar ditinjau dari Motivasi Belajar Siswa. Jurnal Pendidikan Teknik Elektro, 1(2), 121-128.

Sujiantari N.K. 2016. Pengaruh Reward dan Punishment Terhadap Motivasi Belajar Siswa dalam Pembelajaran IPS (Studi Pada SMP Negeri 1 Singaraja Kelas VIII Tahun Ajaran 2015/ 2016). Jurnal Jurusan Pendidikan Ekonomi, 7(2), 1-10.

Suparman. 2010. Gaya Mengajar yang Menyenangkan Siswa. Yogyakarta: Pinus Book Publisher.

Suprapti, E. 2015. Peningkatan Pembelajaran Matematika Anak Usia Dini dengan Microsoft Powerpoint ISpring pada Materi Pengenalan Konsep Bilangan. Jurnal Pedagogi, 2(2), 1-21.

Suprapti, E. 2016. Pengembangan Perangkat Pembelajaran Matematika Model Kooperatif Tipe STAD dengan Media Powerpoint ISpring pada Materi Jajargenjang, Layang-Layang, dan Trapesium di Kelas VII SMP. Journal of Mathematics Education, Science and Technology, $1(1)$, 57- 68.

Suryabrata, S. 1990. Psikologi Pendidikan. Jakarta: PT Rajawali.

Rahayu, R. Ansofino \& Sumarni. 2014. Pengaruh Minat Dan Waktu Belajar Serta Persepsi Siswa Tentang Kompetensi Guru Terhadap Hasil Belajar Siswa Pada Mata Pelajaran Ekonomi di SMAN 1 Bayang Utara. Jurnal Wisuda ke-49 Mahasiswa Prodi Ekonomi, 4(2), 2-11.

Trilling, B \& Fadel, C. 2009. 21st Century Skills: Learning for Life in Our Times. San Fransisco: Josey-Bass.

Ulfah K.R, Santoso, A \& Utaya, S. 2016. Hubungan Motivasi dengan Hasil Belajar IPS. Jurnal Pendidikan: Teori, Penelitian, dan Pengembangan, 1(8), 1607-1611.

Utami M.S. 2014. Upaya Peningkatan Hasil Belajar Siswa Melalui Media Komputer Pada Materi Peninggalan sejarah Hindu Budha di Indonesia Kelas V SDN Kepatihan 04 Kaliwates Jember Tahun 2012/2013. Jurnal Pancaran, 3(4), 175-182.

Winkle, W.S. 1996. Psikologi Pengajaran. Jakarta: Rasindo.

Wulandari, I.S \& Hidayat, T. 2014. Pengaruh Pemberian Reward and Punishment Terhadap Motivasi Belajar Siswa dalam Pembelajaran Passing Bawah Bolavoli (Studi pada Siswa Kelas VIII SMP Negeri 1 Yosowilangun Lumajang). Jurnal Pendidikan Olahraga dan Kesehatan, 2(3), 599-604.

Yana, D. Hajidin \& Safiah, I. 2016. Pemberian Reward dan Punishment Sebagai Upaya Meningkatkan Prestasi Siswa Kelas V di SDN 15 Lhokseumawe. Jurnal IImiah Pendidikan FKIP Unsyiah Guru Sekolah Dasar, 1(2), 11-18.

Yulia, D. 2013. Pengaruh Penggunaan Media Interaktif dan Motivasi Terhadap Hasil Belajar Sejarah Siswa SMA Negeri 1 Gunung Talang. Jurnal Dimensi, 1 (2), 1-9.

Zulyetti. 2014. Penerapan Metode Active Debate dalam Meningkatkan Keterampilan Berbicara pada Mata Pelajaran Bahasa Indonesia. Jurnal Pendidikan Ilmu-Ilmu Sosial, 6(2), 14-21. 